\title{
Natural Water Quality and Its Suitability for Drinking and Irrigation Purposes In the Jungar Basin, Central Asia
}

\section{Bingqi Zhu*}

Key Laboratory of Water Cycle and Related Land Surface Processes, Institute of Geographic Sciences and Natural Resources Researches, Chinese Academy of Sciences, Beijing 100101, China

\begin{abstract}
This study evaluates the natural water suitability for drinking and agricultural purposes in the Jungar Basin in Central Asia. The ionic chemistry of natural waters from the basin changes considerably on a regional scale. The waters are neutral to alkaline and most of them are soft-fresh waters. The total dissolved solid (TDS) varies over two orders of magnitude. Much of the solutes and physicochemical parameters in water are under the highest desirable limits of the World Health Organization (WHO) for drinking purpose and a relationship between sodium adsorption ratio versus EC shows that most waters are of good water quality for irrigation. The effects of local pollution are minimal in the montane and piedmont areas of these watersheds but are significant in the oases and central areas of the drainage basins.
\end{abstract}

Keywords: Central Asia watersheds; Drinking and irrigation; Natural water; Suitability; Water quality

\section{Introduction}

Water quality affects human health and agricultural production to a high extent. Thus, knowledge of hydrochemical characteristics is vital to understand water suitability for various purposes [1]. Natural water (surface water and groundwater) quality in an area is a function of physical and chemical parameters that are greatly influenced by geological formations, climate, and topography [2-7]. In addition, human activities such as industrialization, agriculture, mining, and urbanization produce effluents affect natural water quality $[5,8-10]$. Normally, natural water contamination occurs gradually with little impact in the initial period of deterioration, but if it is not controlled at the right time, this water may not be suitable for any purpose for a long time [11]. Thus the importance of regular monitoring of natural water should be underlined, especially when there are significant changes in industrial, agricultural, and urbanization activities.

The Jungar Basin, including the Erlqis, Jungar and Yili watersheds in northwestern China (No.23, 30 and 31, respectively, in Figure 1), are large watersheds in Central Asia. Until now, despite continuing speculation about the evolution of water resource in these watersheds, very little is known about the hydrochemistry and water quality of natural waters in these watersheds because little chemical data are available.

This study investigates the origin and evolution of solutes in the Jungar Basin from the hydro geochemistry of river water, groundwater, lakes and reservoirs in the areas and focuses on the water quality and its suitability for drinking and irrigation purposes in central Asian. The geochemical processes involved with water-rock interactions, Cation exchange, evaporation and the impacts of human activities on water chemistry in the drainage basins are also taken into account for the interpretation of the data.

\section{Regional Setting}

This study focuses on the Jungar Basin in the northwestern China in Central Asia. The drainage basin includes three watersheds, namely the Yili, Jungar and Erlqis watersheds. The study areas investigated lies between $78^{\circ}$ and $90^{\circ} \mathrm{E}$ and $42^{\circ}$ and $50^{\circ} \mathrm{N}$, covers an area of approximately $603,000 \mathrm{~km}^{2}$ and is bounded by the Tianshan Mountains to the south and by the Altai Mountains to the north. The Jungar watershed is the central part of the study area. It is formed by a structural depression filled with Quaternary and Tertiary unconsolidated sediments as much as $500-1000 \mathrm{~m}$ thick. The large geographic distance from the surrounding oceans and the presence of the rain-shadow effect due to the surrounding orographic conditions are responsible for the arid climate of these watersheds.

These watersheds in Central Asia are controlled by an arid temperate continental climate. The mean annual air temperature is about $5^{\circ} \mathrm{C}$, with a minimum of $-10^{\circ} \mathrm{C}$ to $-20^{\circ} \mathrm{C}$ in January and a maximum of $28^{\circ} \mathrm{C}$ to $33^{\circ} \mathrm{C}$ in August. The regional precipitation is derived mainly from the westerly winds, with a mean annual precipitation rate of $60-150 \mathrm{~mm}$ in the center desert and 200-500 in the surrounding mountainous areas. The potential evapotranspiration is approximately $1000-3500 \mathrm{~mm} / \mathrm{a}$. The Yili and Jungar watersheds are inland watersheds and the Erlqis watershed is a tributary of the Ob River which drains into the Arctic Ocean.

\section{Materials and Methods}

Water sample locations were selected from various parts of the Erlqis, Jungar and Yili watersheds (Figure 2), including river stems, stream channels, hill slopes, wells, lakes, ponds, man-made trenches and reservoirs. The sampling sites were chosen carefully in order to maximize representation of the diverse eco-hydrological environments within the river systems. Taking into account that the tributaries reflect a much broader variety of geologic, biologic, and population patterns than do main stem rivers [12], it was of interest to sample tributary water to look for common features reflected in their hydrochemistry.

The physicochemical parameters such as temperature $(\mathrm{T}), \mathrm{pH}$, electrical conductivity (EC), electrical potential (EP/Eh) and total dissolved solid (TDS) were measured in situ with a calibrated portable Multi-Parameter Analyzer (Eijkelkamp 18.28). The bias of the analytical procedures is $<2 \%$ for $\mathrm{pH}$ and $\mathrm{EP},<1 \%$ for EC, TDS and T. Alkalinity

*Corresponding author: Bingqi Zhu, Key Laboratory of Water Cycle and Related Land Surface Processes, Institute of Geographic Sciences and Natural Resources Researches, Chinese Academy of Sciences, Beijing 100101, China, Tel: +86-10 6488-9333; E-mail: zhubingqi@igsnrr.ac.cn

Received May 04, 2016; Accepted May 12, 2016; Published May 14, 2016

Citation: Zhu B (2016) Natural Water Quality and Its Suitability for Drinking and Irrigation Purposes In the Jungar Basin, Central Asia. J Civil Environ Eng 6: 232 doi:10.4172/2165-784X.1000232

Copyright: (c) 2016 Zhu B. This is an open-access article distributed under the terms of the Creative Commons Attribution License, which permits unrestricted use, distribution, and reproduction in any medium, provided the original author and source are credited. 


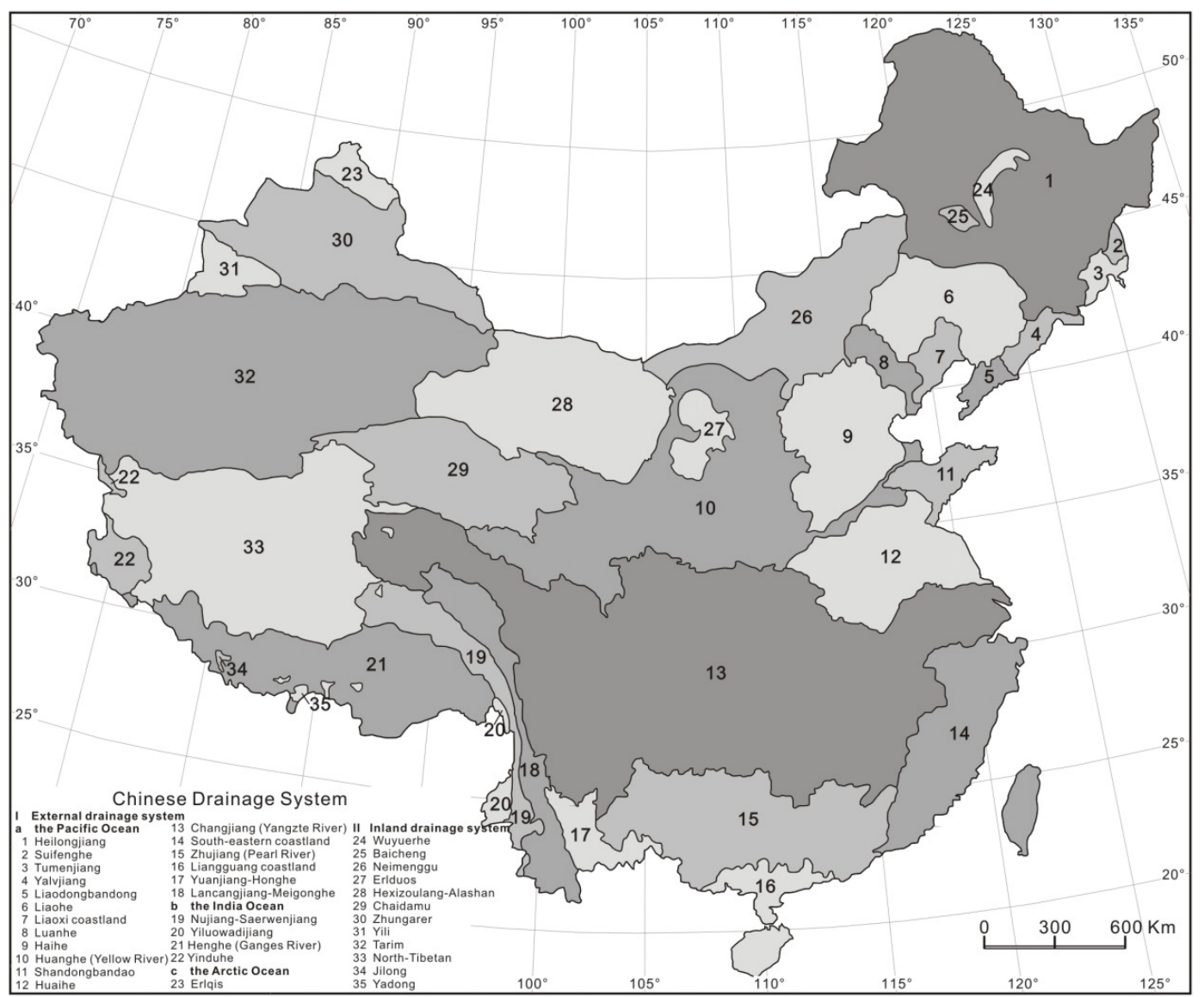

Figure 1: Geographical distribution of drainage systems in China. The 3 watersheds in Northwestern China of Central Asia, numbered 23, 30 and 31, are investigated in this study.

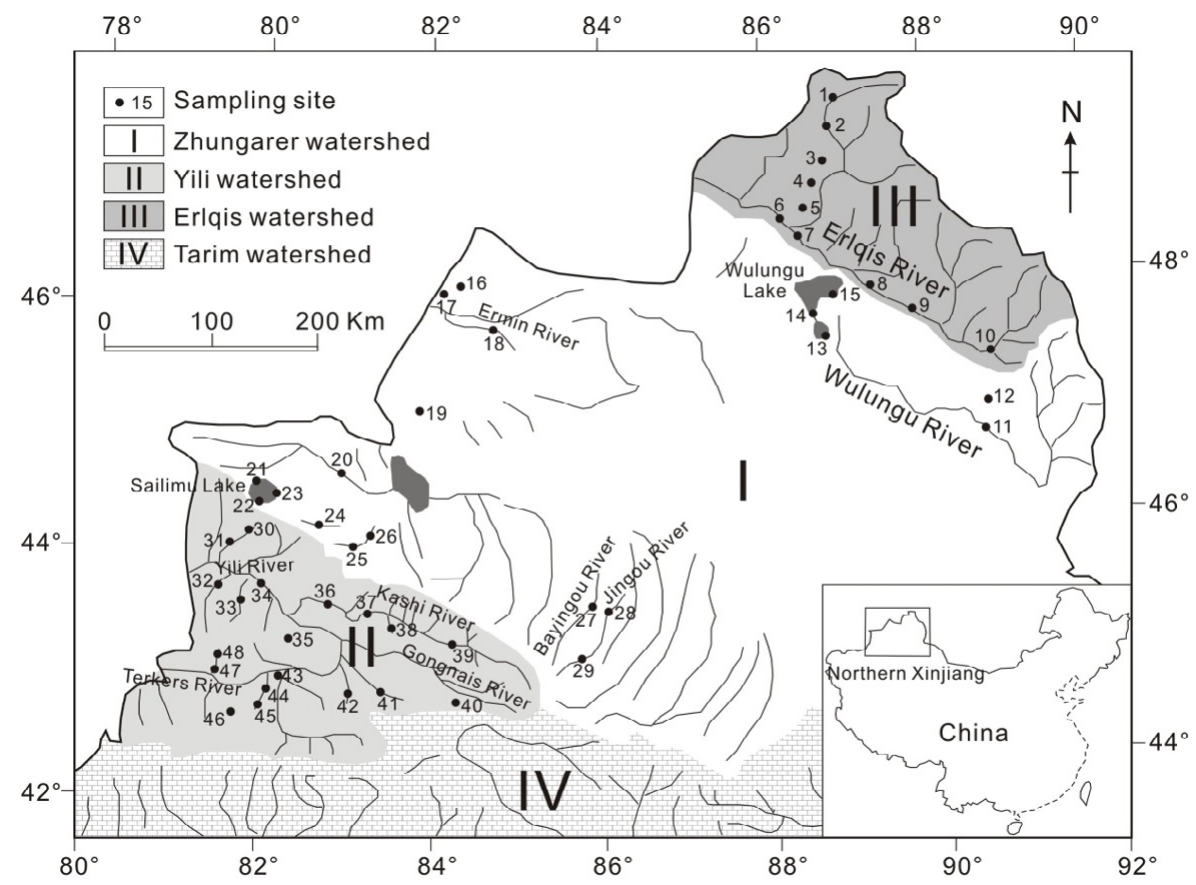

Figure 2: Map of the river distributions and sampling site locations of the 3 studied watersheds in Central Asia. 
(as $\mathrm{HCO}_{3}^{-}$) was determined with a Hach digital titrator using the Gran method. The concentrations of major cations $\left(\mathrm{Li}^{+}, \mathrm{Na}^{+}, \mathrm{NH}_{4}^{+}, \mathrm{K}^{+}\right.$, $\left.\mathrm{Mg}^{2+}, \mathrm{Ca}^{2+}\right)$ and anions $\left(\mathrm{F}^{-}, \mathrm{Cl}^{-}, \mathrm{NO}_{2}^{-}, \mathrm{Br}^{-}, \mathrm{NO}_{3}^{-}, \mathrm{H}_{2} \mathrm{PO}_{4}^{-}, \mathrm{SO}_{4}^{2-}\right)$ were determined by ion chromatography (Dionex 600 IC) with deionized water $(\mathrm{EC}<2.1 \mu \mathrm{S} / \mathrm{cm})$ as the dilute base. A balance of ionic charge and a conservation of mass occur, respectively, indicating a high reliability of the analytical data.

\section{Results and Discussion}

\section{Major hydro geochemical solutes}

The $\mathrm{pH}$ values of the selected water samples vary from 7.0 to 9.81 with an median value of 7.85 indicating that the waters are generally neutral to slightly alkaline. The TDS range between $24.6 \mathrm{mg} / \mathrm{L}$ and 6200 $\mathrm{mg} / \mathrm{L}$, varying over two orders of magnitude from fresh (TDS $<1,000$ $\mathrm{mg} / \mathrm{l})$ to brackish $(1,000 \mathrm{mg} / \mathrm{l}<\mathrm{TDS}<10,000 \mathrm{mg} / \mathrm{l})$.

The variation of major cation $\left(\mathrm{Na}^{+}, \mathrm{K}^{+}, \mathrm{Ca}^{2+}\right.$ and $\left.\mathrm{Mg}^{2+}\right)$ and anion $\left(\mathrm{Cl}, \mathrm{HCO}_{3}^{-}, \mathrm{SO}_{4}^{2-}\right.$ and $\left.\mathrm{NO}_{3}^{-}\right)$concentrations measured in the studied water samples is illustrated in the Box and Whisker plot (Figure 3), where $\mathrm{Ca}^{2+}$ and $\mathrm{HCO}_{3}^{-}$are the dominant cation and anion, respectively. Nevertheless, many of the water samples contained high $\mathrm{SO}_{4}{ }^{2-}$ concentrations. The order of relative abundance of major cations in these waters is $\mathrm{Ca}^{2+}>\mathrm{Na}^{+}>\mathrm{Mg}^{2+}>\mathrm{K}^{+}$(on $\mathrm{mg} / \mathrm{L}$ basis) while that of anions is $\mathrm{HCO}_{3}^{-}>\mathrm{SO}_{4}{ }^{2-}>\mathrm{Cl}^{-}>\mathrm{NO}_{3}{ }^{-}$. Large percentages of contribution to the TDS of water samples are from $\mathrm{HCO}_{3}^{-}, \mathrm{Ca}^{2+}$ and $\mathrm{SO}_{4}^{2-}$.

The concentrations of major ions measured in the studied water samples are presented in the Piper Trilinear Plot (Figure 4). This figure shows that the natural waters in the study area can be broadly divided into 4 major types: type- $1, \mathrm{Ca}-\mathrm{HCO}_{3}$; type-2, $\mathrm{Ca}-\mathrm{Mg}-\mathrm{HCO}_{3}-\mathrm{SO}_{4}$; type3, $\mathrm{Ca}-\mathrm{Mg}-\mathrm{SO}_{4}$ and type-4, $\mathrm{Na}-\mathrm{SO}_{4}$. Major waters are of $\mathrm{Ca}-\mathrm{HCO}_{3}, \mathrm{Ca}-$ $\mathrm{Mg}-\mathrm{HCO}_{3}-\mathrm{SO}_{4}$ and $\mathrm{Ca}-\mathrm{Mg}-\mathrm{SO}_{4}$ types and their chemical properties are dominated by alkaline earths and the $\mathrm{HCO}_{3}{ }^{-}$and $\mathrm{SO}_{4}{ }^{2-}$ anions. The $\mathrm{Na}-\mathrm{SO}_{4}$ type water occupies the section near the right corner of the central diamond. These waters are of the saline water type. Water types distributed in the Erlqis and Yili watersheds are mainly type-1 and type-2, while those in the Jungar watershed are type- 1 and type2 in the mountain areas and type- 3 and type- 4 in desert plain areas. In general, water types of the 3 watersheds display a kind of zonal distribution from mountainous area to pediment, to oases and to desert plain, namely a variational trend in rough order of type-1, type2 , type- 3 and type- 4 .

\section{Water quality and its suitability for drinking and irrigation purposes}

The natural water quality for drinking and irrigation purposes in these watersheds is assessed based on the recommended standards of the World Health Organization [13] and the National Standard of the People's Republic of China [14].

Drinking water: The TDS versus TH plot (Figure 5a) shows that most surface and groundwater samples in these watersheds are softfresh and hard-fresh water. Several water samples with high TDS $(>1000 \mathrm{mg} / \mathrm{L})$ and $\mathrm{TH}(>300 \mathrm{mg} / \mathrm{L})$ values, classed as hard-brackish water in Figure $5 \mathrm{a}$, are from the Jungar watershed. Total dissolved solids (TDS), total hardness (TH), $\mathrm{pH}$ and the concentrations of $\mathrm{Ca}^{2+}, \mathrm{Mg}^{2+}$, $\mathrm{Na}^{+}, \mathrm{Cl}^{-}, \mathrm{SO}_{4}^{2-}, \mathrm{NO}_{3}^{-}$and $\mathrm{F}^{-}$in about $0 \sim 20 \%$ of the studied water samples are higher than the highest desirable limits of $1000,450,8.5,75,30,200$, $250,250,50$, and $1.5 \mathrm{mg} / \mathrm{L}$ respectively, prescribed for drinking purpose by WHO [13] and NSPRC [14]. All groundwater samples in this study are below the limits of the WHO [13] and NSPRC [14].
Irrigation water: To assess the water quality for irrigation purposes, the $\mathrm{Na}$ or alkali-hazard expressed in terms of sodium adsorption ratio (SAR) is widely used. If waters used for irrigation are high in $\mathrm{Na}^{+}$and low in $\mathrm{Ca}^{2+}$, the ion-exchange sites may become saturated with $\mathrm{Na}^{+}$, which destroys the soil structure, because of dispersion of the clay particles. Such soils reduce plant growth. The SAR for the studied waters is computed, using the formula (Hem, 1991): $\mathrm{SAR}=\mathrm{Na}^{+} /\left(\left(\mathrm{Ca}^{2+}\right.\right.$ $\left.+\mathrm{Mg}^{2+}\right)(2)^{0.5}$, where the ion concentrations are expressed in meq/L. The computed SAR values for water samples in the 3 watersheds range from 0.06 to 28.3, with an average value of 1.97. The SAR versus EC plot (Figure $5 \mathrm{~b}$ ) shows that most surface water samples are of good water quality (75\%). A small number of surface water samples are of moderate quality (7\%) and poor quality (18\%) types. The 4 groundwater samples analyzed are all of good water quality. The moderate to bad quality waters have higher $\mathrm{Na}^{+}$concentrations.

It is generally known that agricultural practices can pose a serious threat to natural water, particularly groundwater quality. It is especially true in arid areas as the growing season with its high water demands coincides with the dry period. In addition, the use of fertilizers with a strong polluting effect on groundwater is a widespread agricultural practice in northwestern China. The use of $\mathrm{N}$ fertilizers in particular is well established throughout the world and increased use has led to extremely high $\mathrm{NO}_{3}{ }^{-}$concentrations in ground waters [15]. Compared with the $\mathrm{NO}_{3}$ - contents $(0.5 \sim 7.7 \mathrm{mg} / \mathrm{L})$ in the studied surface waters, groundwater samples (such as samples 16, 25, 26) collected from different irrigated oases in the Jungar watershed have evidently higher concentrations of $\mathrm{NO}_{3}^{-}(22-37 \mathrm{mg} / \mathrm{L})$, indicating the strong influence of local agricultural practices in these zones.

The 3 inorganic $\mathrm{N}$ species $\left(\mathrm{NO}_{3}^{-}, \mathrm{NO}_{2}^{-}, \mathrm{NH}_{4}^{+}\right)$have different measured distributions in the studied waters. Nitrite was not detected in any sample, and $\mathrm{NH}_{4}^{+}$only occurred in a few samples in this study. Nitrate was detected in most of the studied samples. Its concentrations do not show any systematic variations with any ion concentrations and parameters or along the river courses, suggesting that point sources, presumably of anthropogenic origin, play an important role. In comparison with the mean value $(2.46 \mathrm{mg} / \mathrm{L})$ of $\mathrm{NO}_{3}^{-}$in this study, somewhat higher concentrations of $\mathrm{NO}_{3}^{-}(7 \sim 37 \mathrm{mg} / \mathrm{L})$ were observed in several studied samples collected from oases with a dense population or farming, particularly groundwater and river water taken from agricultural and residential regions. This indicates an evident anthropogenic input of $\mathrm{NO}_{3}^{-}$in these places, probably from agricultural activities (fertilizers) or municipal and industrial discharges. These inputs are possibly modified by biological processes in the river itself, with oxidation of $\mathrm{NH}_{4}^{+}$to $\mathrm{NO}_{2}^{-}$and subsequently to $\mathrm{NO}_{3}^{-}$[12], which could explain the distribution patterns of the 3 inorganic $\mathrm{N}$ species in the studied waters. Phosphorus species, the limiting factors of autotrophic life, were not detected in any sample in this study.

\section{Summary and conclusion}

This paper focused on the major ion chemistry of natural water in 3 watersheds (the Erlqis, Jungar and Yili) in Central Asia to characterize their hydro geochemistries and water qualities. Results show that the natural waters in Central Asia are neutral to slightly alkaline in nature and most of them are soft-fresh water. The water qualities vary from fresh to brackish with a mean TDS concentration of $580 \mathrm{mg} / \mathrm{L}$, about 4.6 times that of the world spatial median. Four major water types $\mathrm{Ca}-\mathrm{HCO}_{3}, \mathrm{Ca}-\mathrm{Mg}-\mathrm{HCO}_{3}-\mathrm{SO}_{4}, \mathrm{Ca}-\mathrm{Mg}-\mathrm{SO}_{4}$ and $\mathrm{Na}-\mathrm{SO}_{4}$ were identified using the Piper diagram and among them, $\mathrm{Ca}-\mathrm{HCO}_{3}$ is the principal type. Total dissolved solids (TDS), total hardness (TH), $\mathrm{pH}$ and the concentrations of $\mathrm{Ca}^{2+}, \mathrm{Mg}^{2+}, \mathrm{Na}^{+}, \mathrm{Cl}^{-}, \mathrm{SO}_{4}^{2-}, \mathrm{NO}_{3}^{-}$and $\mathrm{F}^{-}$in 


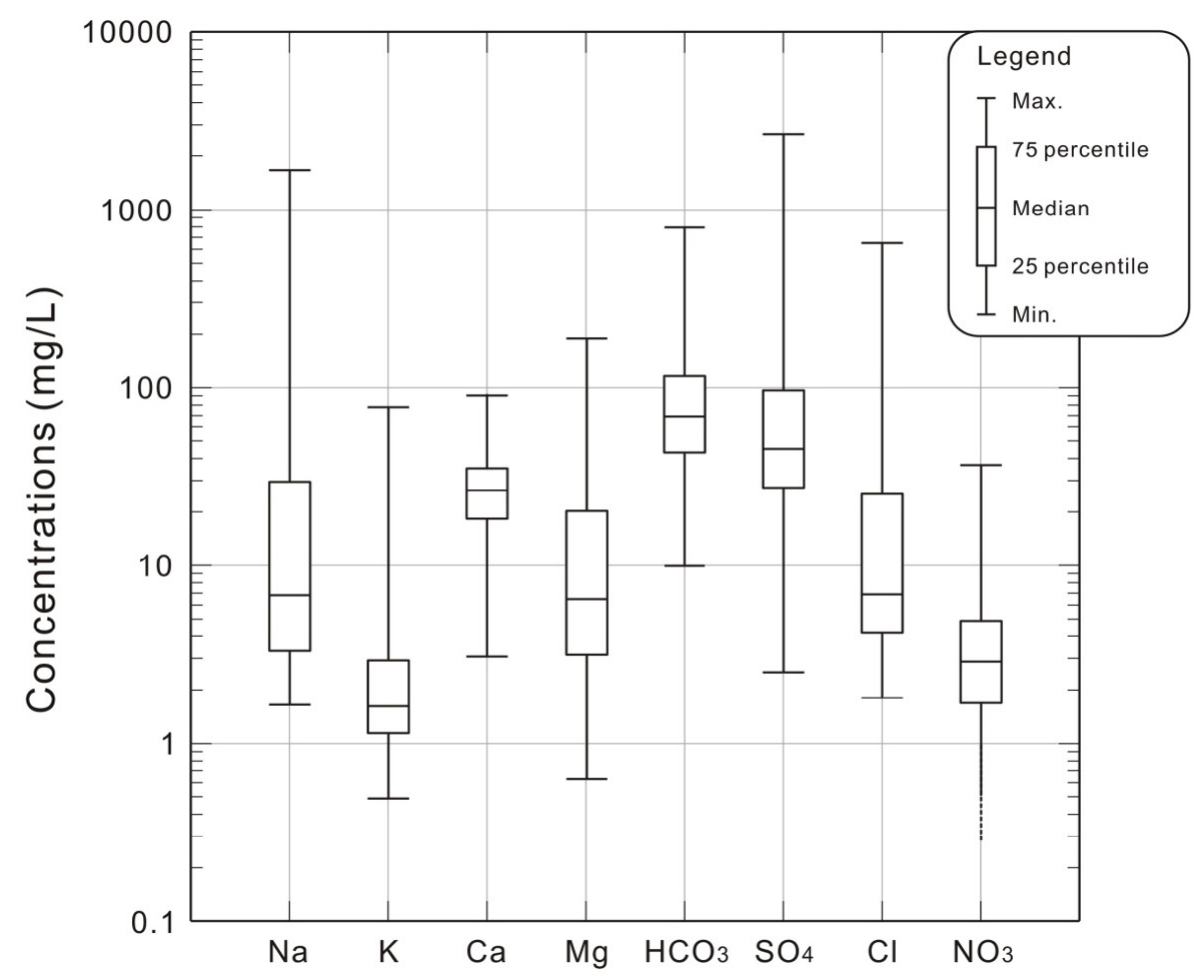

Figure 3: Box and whisker plots showing the variation of major ion concentrations in the studied water samples.

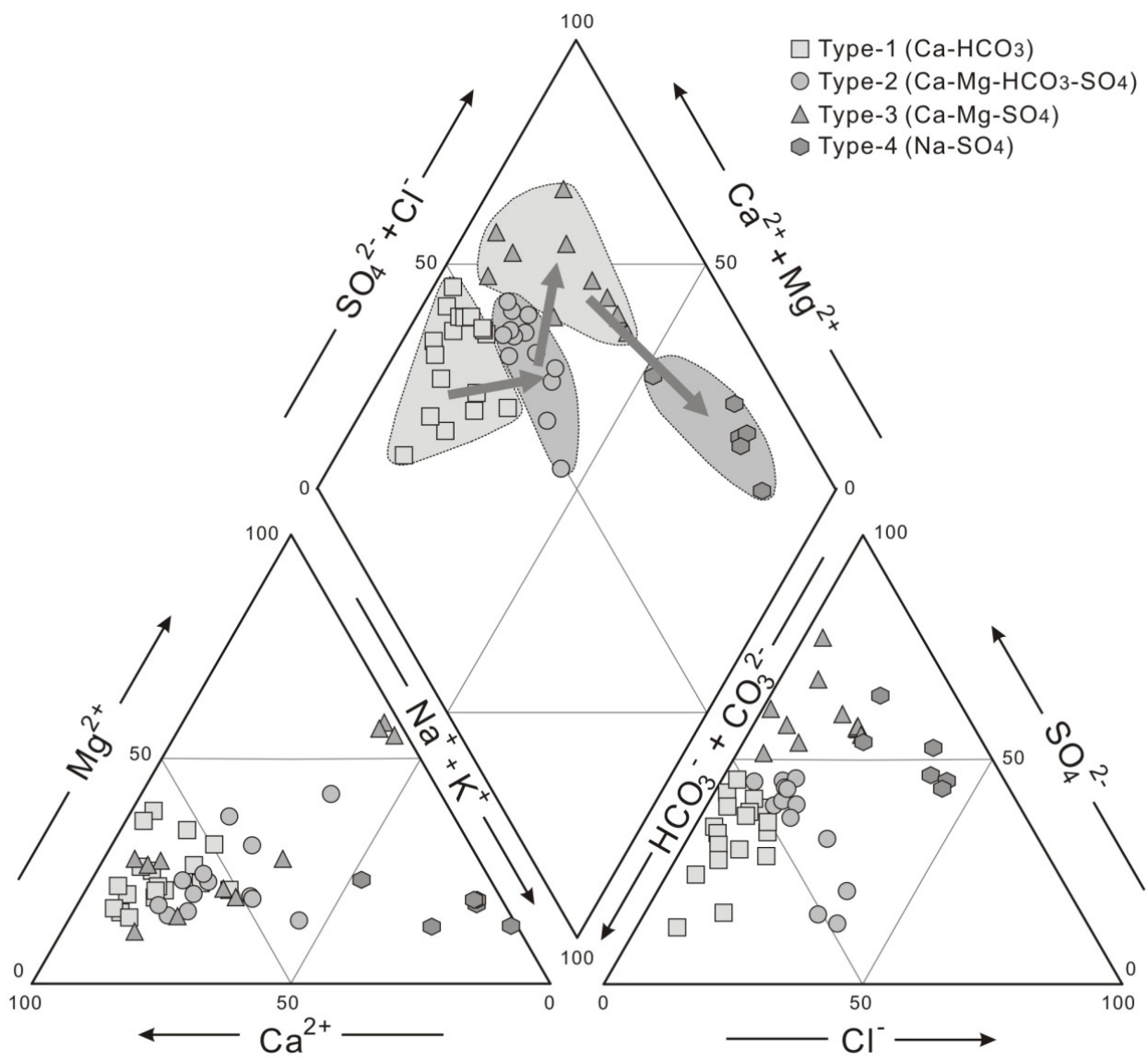

Figure 4: Piper diagram showing major ion composition of the natural waters in the three watersheds in Central Asia. 

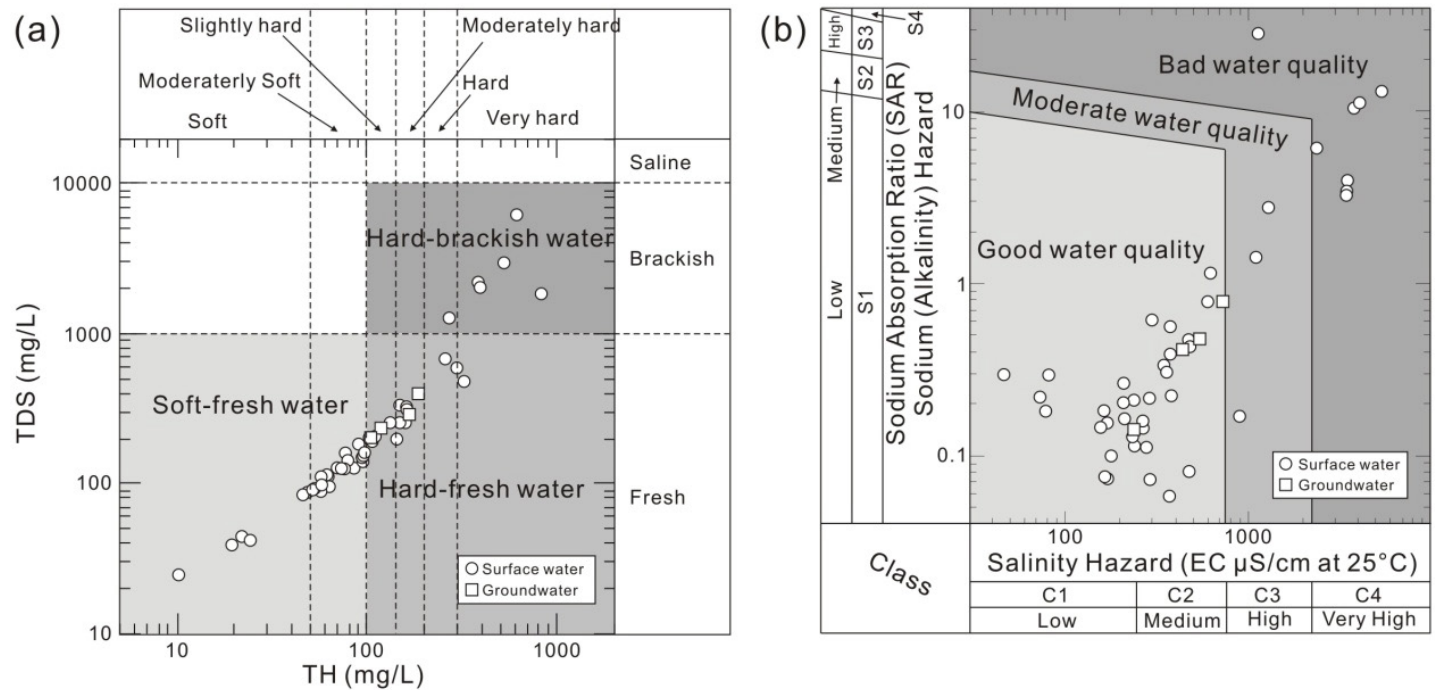

Figure 5: Natural water quality for drinking and irrigation purposes in the Erlqis, Jungar and Yili watersheds in Central Asia.

about $0 \sim 20 \%$ of the studied water samples are higher than the highest desirable limits of drinking water prescribed for drinking purpose by WHO [13] and NSPRC [14]. Most groundwater samples are below the limits of the WHO [13] and NSPRC [14]. Regards to the water quality for irrigation purposes, most surface water samples are of good water quality (75\%). A small number of surface water samples are of moderate quality (7\%) and poor quality (18\%). The groundwater samples are all of good water quality for irrigation purposes. The moderate to bad quality waters have higher $\mathrm{Na}^{+}$concentrations. Point sources, presumably of anthropogenic origin, play an important role in oasis areas. The effects of local pollution are minimal in the montane and piedmont areas but are more significant in the oases and the central areas of the drainage basins.

\section{Acknowledgement}

The study was funded by the Kezhen Young Talent Project of the IGSNRRCAS (grant no. 2013RC101) and the National Natural Science Foundation of China (grant nos. 41371060, 41225001, 41271049).

\section{References}

1. Cicchella D, Albanese S, De Vivo B, Dinelli E, Giaccio L, et al. (2010) Trace elements and ions in Italian bottled mineral waters: identification of anomalous values and human health related effects. J Geochem Explor 107: 336-349.

2. Helena B, Pardo R, Vega M, Barrado E, Fernandez J (2000) Temporal evolution of groundwater composition in an alluvial aquifer (Pisuerga River, Spain) by principal component analysis. Water Res 34: 807-816.

3. Subramani T, Elango L, Damodarasamy SR (2005) Groundwater quality and its suitability for drinking and agricultural use in Chithar River Basin, Tamil Nadu, India. Environ Geol 47: 1099-1110.

4. Zhu B, Yang X (2007) The ion chemistry of surface and ground waters in the Taklimakan Desert of Tarim Basin, western China. Chinese Science Bulletin 52: $2123-2129$

5. Zhu B, Yang X, Rioual P, Qin X, Liu Z, et al. (2011) Hydrogeochemistry of three watersheds (the Erlqis, Zhungarer and Yili) in northern Xinjiang, NW China. Applied Geochemistry 26: 1535-1548.

6. Zhu B, Yu J, Qin X, Rioual P, Xiong H (2012) Climatic and geological factors contributing to the natural water chemistry in an arid environment from watersheds in Northern Xinjiang, China. Geomorphol 153-154:102-114.

7. Balasubramanian $N$, Sivasubramanian $P$, Soundranayagam J, Chandrasekar N, Gowtham B (2015) Groundwater classification and its suitability in Kadaladi, Ramanathapuram, India using GIS techniques. Environ Earth Sci 57: 1-23.
8. Dinelli E, Lima A, De Vivo B, Albanese S, Cicchella D, et al. (2010) Hydrogeochemical analysis on Italian bottled mineral waters: effects of geology. J Geochem Explor 107: 317-335.

9. Singh A, Mondal GC, Singh TB, Singh S, Tewary BK, et al. (2012) Hydrogeochemical processes and quality assessment of groundwater in Dumka and Jamtara districts, Jharkhand, India. Environ Earth Sci 67: 21752191.

10. Oyarzun R, Jofre E, Morales P, Maturana H, Oyarzun J, et al. (2015) A hydrogeochemistry and isotopic approach for the assessment of surface water-groundwater dynamics in an arid basin: the Limarl' watershed, NorthCentral Chile. Environ Earth Sci 73: 39-55.

11. Rao YS, Reddy TV, Nayudu PT (1997) Groundwater quality in the Niva River basin, Chittoor district, Andhra Pradesh, India. Environ Geol 32: 56-63.

12. Pawellek F, Frauenstein F, Veizer J (2002) Hydrochemistry and isotope geochemistry of the upper Danube River. Geochimica \& Cosmochimica Acta 66:3839-3854

13. WHO (2008) Guidelines for drinking water quality. World Health Organization, Geneva.

14. NSPRC (2002) Standards for drinking water quality (GB3828-2002). Nationa Standard of People's Republic of China.

15. Stigter TY, Van Ooijen SPJ, Post VEA, Appelo CAJ, Dill AMMC (1998) A hydrogeological and hydrochemical explanation of the groundwater composition under irrigated land in a Mediterranean environment, Algarve, Portugal. J Hydrol 208: 262-279. 